\title{
GEOEDUCAÇÃO DAS REPRESENTAÇÕES RELIGIOSAS
}

\author{
geoeducation of religious representations
}

Christian Dennys Monteiro de Oliveira *

\begin{abstract}
Resumo
As representações patrimoniais da festividade religiosa, realizada em Huelva (Espanha), por ocasião do traslado da imagem da Virgem do Rocio à sede deste município, entre agosto/2012 e maio/2013, compõe a base desta reflexão. A investigação recolheu opiniões de professores e alunos de duas escolas secundárias da localidade, com o objetivo de caracterizar as significações educativas de um evento extraordinário e articulador de expressões culturais. A leitura dos vínculos geográficos entre o patrimônio e as formas de difusão (midiática e turística), nos levou a desenvolver o conceito de "geoeducação". Estruturado a partir das perspectivas fenomenológicas de leituras geográficas fornecidas por Dardel (2011) e Relph (2012), a "geoeducação" emerge como um modelo não formal de gerar sentido dos lugares pela ritualidade festiva. Sentido que responde ao reconhecimento de forças simbólicas vetoriais (comunicativas, turísticas e cenográficas) - intermediadas pela questão patrimonial contemporânea.
\end{abstract}

Palavras-Chave: Traslado; Representação; Geoeducação; Patrimônio.

\begin{abstract}
The equity representations of religious festival held in Huelva (Spain), on the occasion of the transfer of the image of the Virgin of Rocio seat of the county between August 2012 and May 2013 forms the basis of this reflection. The research collected opinions of teachers and students from two secondary schools in the locality, with the aim of characterizing the educational meanings of an extraordinary event and organizer of cultural expressions. Reading the geographical links between heritage and forms of dissemination (media and tourism), led us to develop the concept of "geoeducation". Structured from the phenomenological perspectives of geographical readings provided by Dardel (2011) and Relph (2012), the "geoeducation" emerges not as a formal model to generate the sense of festive places rituality. Sense that responds to the recognition of vector symbolic forces (communicative, and scenographic tourist) - brokered by contemporary equity issue
\end{abstract}

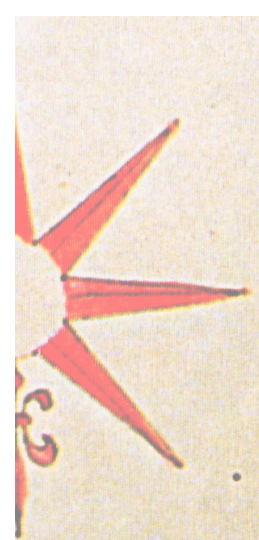

Key words: Pickups; Representation; Geoeducation; Heritage; Symbolic Vectors.

\section{Resumen}

Las representaciones del patrimonio de la fiesta religiosa celebrada en Huelva (España), con traslado de la imagen de la Virgen del Rocío (de agosto 2012 hacia septiembre 2013) constituye la base de esta reflexión. La investigación recoge las opiniones de profesores y estudiantes de escuelas secundarias de Almonte, con el objetivo de caracterizar los significados educativos de un evento singular y articulador de las expresiones culturales. La lectura de los vínculos geográficos entre el patrimonio y las formas de difusión (medios y turismo), nos llevó a desarrollar el concepto de "geoeducação". Estructurado a partir de las perspectivas fenomenológicas de lecturas geográficas proporcionadas por Dardel (2011) y Relph (2012), la geoeducação surge como un modelo formal para generar el sentido de lugares en la ritualidad festiva. Sentido que responde al reconocimiento de las fuerzas simbólicas vectoriales (turísticos, comunicativa y escenográfica) - mediado por el reto patrimonial de hoy.

Palabras clave: Pastillas; Representación; Geoeducación; Patrimonio; Vectoriales simbólicos.

(*) Prof. Dr. do Programa de Pós-Graduação em Geografia da Universidade Federaldo Ceará - Campus do Pici, Bloco 911, CEP: 60.440-900, Fortaleza (CE), Brasil. Tel: (+ 55 11) 3366-9855 - cdmo49@yahoo.com.br 


\section{INTRODUÇÃO}

Em Agosto de 2012, o Santuário Católico do povoado de El Rocio, no município de Almonte (Huelva-Espanha) viveu um instigante episódio de reapropriação devocional mariana. Naquela manhã do dia 20 de agosto, já a cinco dias do ano jubileu decretado pelo Papa Bento XVI, a Virgem do Rocio realizou o mais imponente traslado peregrino de sua história, comemorando os 200 anos do Bicentenário da festividade conhecida como "Rocío Chico". Para a cidade sede, aquele jubileu correspondia a mais um ato, entre tantos, de confirmação do incomparável peso simbólico e administrativo que a Irmandade Matriz de Almonte desempenha na patrimonialização desta cultural devocional. $\mathrm{O}$ que nos permite indagar o quanto as demais Irmandades Filiais - conjunto das outras 112 associações com legitimo direito canônico de veneração à Virgem do Rocio - além da Igreja católica episcopal e o poder público - cooperam para essa confirmação. Sem dúvida, um interessante objeto de reflexão para a continuidade de nossos estudos.

Mas o foco central da análise que se inicia com a representação geográfico-educativa desse evento, direciona o olhar para as expressões escolares do acolhimento cultural desse momento simbólico. A visita da Santa ocorre a cada sete anos. E a anterior deu-se em 2005, distanciando da memória anual as lembranças dos mais jovens e não trazendo aos mais maduros a densidade mítica e logística que o Jubileu do Bicentenário despertava. A Municipalidade e Irmandade de Almonte, por intermédio da concessão canônica do então Papa Bento XVI, obtiveram registro do Ano Jubilar Mariano (na Cidade, Município e Aldeia do Rocio). O site oficial das comemorações extraordinárias faz a seguinte apresentação desta festividade:

O Ano Jubilar Mariano da Virgem do Rocio, dada por Sua Santidade o Papa Bento XVI, é um evento único e especial, religiosa e culturalmente, que irá saudar os peregrinos de todo o mundo e gerar um espaço privilegiado onde: valores cristãos, a interculturalidade, a solidariedade e a responsabilidade social são os principais valores a serem compartilhados entre todos os participantes. Nosso principal objetivo é promover, neste palco Jubileu do Rocio, sinergia e cooperação interinstitucional em benefício dos cidadãos de uma comunidade que inclui mais de 1 milhão de pessoas em todo o mundo , e fortalecer os valores importantes, como a tradição, ambiente onde ele ocorre, além de um amplo desenvolvimento cultural que gira em torno da coesão social. É importante rever também a declaração de evento excepcional interesse público foi incluído pelo Governo da Espanha no Orçamento do Estado, fato que, sem dúvida, servirá como um instrumento importante para atingir nossos objetivos. (Tradução nossa do texto original, disponível em http://www.rociojubilar.net/. Acesso em 03 de Maio de 2014).

A concepção mais relevante nessa apresentação é mostrar o evento como expressão cultural, relevante e institucionalizado, tanto para a Igreja como para o Estado espanhol. O que permite tratar a festa em uma articulação eclesial, civil e cultural, como investimento plenamente justificado para superação dos problemas socioeconômicos e ambientais que atingem a Espanha desde o início da crise financeira de 2008. Para Almonte o traslado deste biênio poderia representar um significativo ganho de efeito turístico e patrimonial, que na condição da sede municipal assume o posto de centro de peregrinações em homenagem a Virgem do Rocio, no decorrer de nove meses do ano (19 de agosto de 2012 a 12 de maio de 2013)

No Rocio Chico de 2012, na segunda dezena de agosto, condensava-se uma atmosfera de forte apelo emocional e patrimonial, pois sua realização marcou a definitiva abertura do Ano Jubilar Mariano. O traslado processional coincidiu - em seu ciclo de 7 anos prefixados a partir de 1949 - com o Bicentenário da peregrinação da Irmandade Matriz de Almonte a sua Aldeia Sagrada. E permitiu a abertura de um questionamento direto a respeito de sua representação simbólica e vetorial frente ao patrimônio educativo ali expresso. Em que medida a juventude local, estudantes das escolas de ensino básico - na Espanha, correspondendo a Escola Secundária e ao Bacchirelatto - compreendiam a força dessa representação patrimonial? E consequentemente, como se posicionavam os docentes diretamente envolvidos com a formação desses conteúdos culturais? Estaria a escola 
cooperando com ou reordenando um processo religioso que modificava completamente a rotina da cidade de Almonte?

Tais indagações tiveram uma versão preliminar no estudo sobre a formação do patrimonial, desenvolvido no contexto da Romaria de Pentecoste (Rocío Grande) de 2011. Seus primeiros elementos identificadores foram publicados como trabalho, livro e artigo diretamente vinculados (OLIVEIRA, 2012). Mas necessitou de um tratamento específico na interlocução direta com a escola regular, a partir destas reflexões, o que se tornou oportuno em janeiro de 2013, quando a parte empírica da investigação foi realizada. Os itens nesta parte inicial exploram, portanto, a contextualização central da oportunidade que o Traslado de 2012/2013 fomentou. Segue-se à discussão, suas representações traduzidas pela tabulação dos questionários realizados e avança na reflexão sobre a natureza fenomenológica e vetorial da Geoeducação, consolidada por festividades equivalentes até reencontrar uma proposição mais epistemológica na Geografia relacional no campo do imaginário político-religioso. A conclusão nos permitirá dizer, com a metáfora do retorno da Virgem ao Santuário tradicional do Rocio, se os eventos do Traslado e Jubileu foram apenas expedientes extraordinários ou se existe, em potência, uma continuidade espacial da Festa Religiosa, que a Educação Patrimonial (IPCE; OEPE, 2012) especialmente a que envolveria o Ensino de Geografia, ainda se recusa a absorver.

\section{A RELIGIOSIDADE E O EVENTO}

As formas de religiosidade e atos processionais no interior de Andaluzia se harmonizam com toda uma relação político-cultural de renovação mítica da reconquista cristã da Península Ibérica. O território andaluz representa o último foco de resistência moura, no processo medieval que se estendeu do Séc. XI ao XV, mais precisamente no referencial ano de 1492, cuja efeméride marca simultaneamente a conquista de Granada (Andaluzia Oriental) e a chegada das Caravelas Colombinas em terras Americanas. No final do Século XVI, Sevilha, capital andaluza, polarizava a espoliação das riquezas coloniais e traduzia na Espanha meridional o esplendor das formas de representação agrária do Mercantilismo Ibérico. Embora rivalizando com Portugal certa hegemonia sobre as rotas do Atlântico, a Andaluzia entrou em estagnação. O antropólogo Rodriguez Becerra, estudando a religiosidade andaluza, apresenta um desenho cultural do processo:

La religiosidad andaluza la caracterizan algunos por su anacronismo y dependencia que tiene su origen en el retraso económico y en el tardío acceso generalizado de los jóvenes a la enseñanza secundaria y universitaria...y se expresa por sus manifestaciones barrocas, probablemente por corresponder este período con la última etapa de esplendor de la región y de sus ciudades. La estética barroca, reelaborada por la concepción romántica que exalta la sensualidad, se ha convertido en un canon riguroso del que salirse es casi imposible. (RODRIGUEZ BECERRA, 2006, 25).

Portanto, um desenvolvimento econômico limitado e demorado acesso a escolaridade média - no Brasil, equivalendo aos $8^{\circ}$ e $9^{\circ}$ anos do Ensino Fundamental, somad os aos três anos do Médio - e superior ajudariam a justificar a adesão a uma religiosidade barroca. Já a memória do esplendor andaluz, retida em um lugar mítico do império espanhol, ajudaria fixar o romantismo dos ritos e a sensualidade capturada do cosmopolita convívio com outros povos (ciganos, mouros, latino americanos). A leitura do autor, entretanto, está pautada na comparação entre a religiosidade andaluza e formalismos rituais católicos, menos exultantes e presentes em outras regiões espanholas. Haveria outros fatores mais hodiernos?

As imagens constatadas, na vivência do cotidiano de Huelva (província andaluza que polarizou o Bicentenário), durante a permanência da Virgem em Almonte, induzem-nos a hipótese mais sincrônica a respeito dos vínculos entre a religiosidade e o evento. Não se trata somente de uma tradição barroca e agrária da qual não se consegue desvincular. A realidade regional andaluza representa uma sintonia quase modelar com o processo contemporâneo de construção, democrática 
e confederativa, do Estado Espanhol das Comunidades Autonômicas (HENARES CUÉLLAR, 2010). E neste quadro, a articulação dos bens patrimoniais andaluzes - incluindo as festividades e seus cenários - evoluiu conforme uma leitura vinculada à produção cultural dos bens históricos patrimoniais. (ESCALERA REYES, 2002)
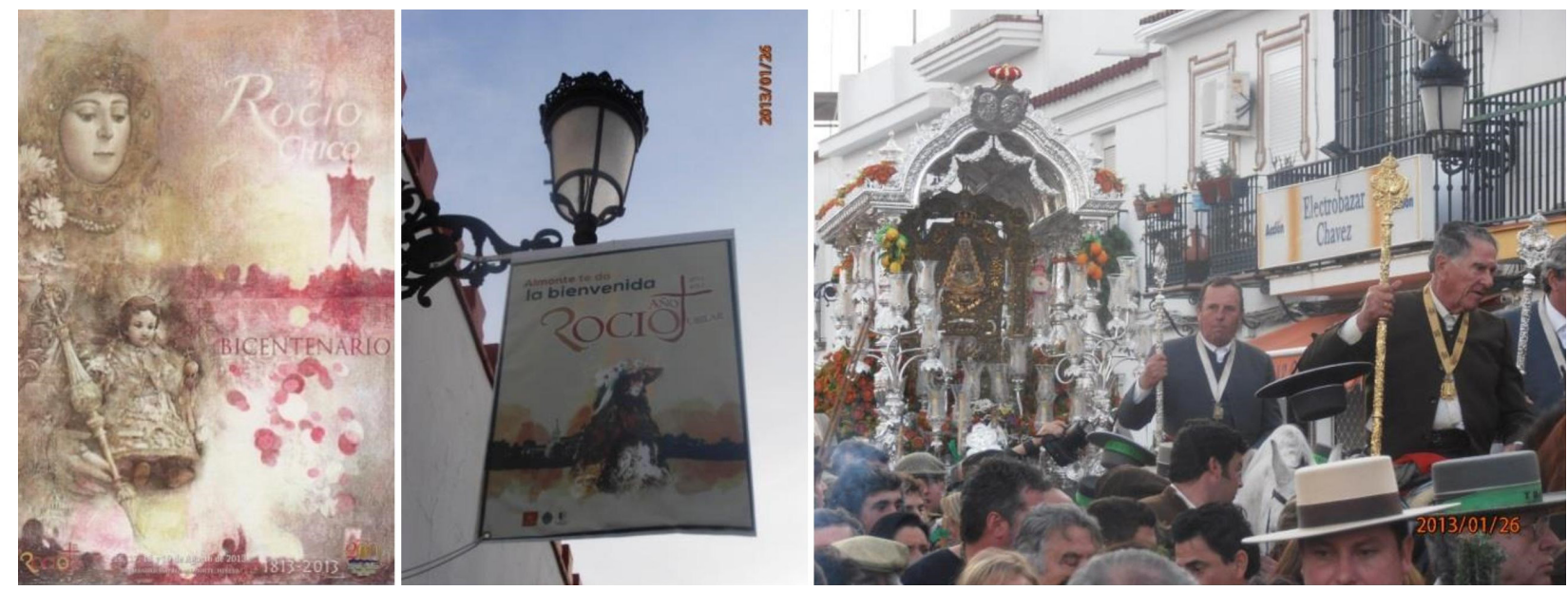

Figura 1 - Cartaz do Bicentenário e Ano Jubilar em Almonte saudando a Irmandade de Triana - Fonte: Imagens do arquivo pessoal do Autor

Conforme afirma Castillo Ruiz, ao comentar os vínculos territoriais da Lei do Patrimônio Histórico Espanhol (LEPH 16/1985), "el patrimonio cultural se observa desde la diversidad regional o de los pueblos de España mientras que lo que afecta al común se entiende como legalidad preestablecida e indiscutida" (HENARES CUÉLLAR, 2010, 59). Raciocínio que evoca todo um incentivo jurídico à construção política de eventos capazes de celebrar o incremento autonômico da cultura espanhola nas formas regionais de geograficidade andaluza. Neste sentido, a religiosidade não se explica, exclusivamente pela resistência das tradições históricas de uma região; mas pelo desenho patrimonial que determinados eventos religiosos, em cenários locais adequadamente atualizados, promovem em franco diálogo com as condições geográficas vigentes (VICENTE CARMONA, 2010). Incentivo turístico, recuperação econômica de uma crise financeira, respostas às demandas sociais por serviços públicos tecnologicamente qualificados e espaço político de discussão das organizações locais/ regionais. Ao receber o desfile comemorativo dos 200 anos da maior Irmandade rocieira - a Irmandade de Triana, sediada em Sevilla (capital) - Almonte reconfigura-se como espaço de poder simbólico ativo. Não só religioso ou ilustrativo. Eis um valor diferencial a ser debatido.

\section{CIDADE E ESCOLARIDADE}

Huelva, a província mais ocidental de Andaluzia, faz suas divisas territoriais com o Algarve português (a leste), com Badajoz, Extremadura (a norte) e as províncias andaluzas de Sevilla e Cádiz (a oeste), onde também se localiza município de Almonte (http://www.diphuelva.es/). Possui quatro demarcações geoambientais, conhecidas por "Comarcas Naturales": Sierra (ao norte, domínios da Serra Morena), Andévalo (área de histórica exploração mineral), Condado-Campina (marcada pela produção vinícola) e Costa (centrada na capital portuária Huelva). Coincidindo com os domínios da costa oriental, o complexo do Parque Doñana (patrimônio autonômico, nacional e mundial) ocupa boa parte do território “almontenho". Não só delimita sua franja costeira, mas consolida o cenário rural, de terrenos planos, arenosos e alagadiços no qual se articula uma formação agropecuária e extrativista, indispensáveis ao contexto festivo rocieiro.

O Guia de Turismo de Huelva (edição 2009/2010) - Huelva de La Luz - bem como o site oficial do "Ayuntamiento" (Prefeitura) de governo reafirmam a condição de Almonte como sede de um município costeiro, diretamente implicado pela cultura religiosa devocional à Virgem do 
Rocio. Nesse sentido, as duas grandes peregrinações anuais, de Maio/Junho (Rocio Grande) e de Agosto (Rocio Chico), articulam-se às tradições rurais e equestres do entorno do Parque Doñana, trazendo para Almonte uma polaridade cultural peculiar no desenvolvimento turístico de Huelva (MUÑOZ BORT, 2007). Por esta razão a celebração extraordinária dos traslados, a cada sete anos, representa um afluxo de grandes investimentos político-econômico. O que torna documentos como o estudo produzido por Julio Flores Cala, Historia y documentos de los traslados de la Virgen del Rocío a la Villa de Almonte 1607-2005, um aporte técnico e científico indispensável à gestão do desenvolvimento urbano. A crescente preocupação sobre seus três núcleos de urbanização (a Sede, a aldeia El Rocio, e o Balneário atlântico de Matalascañas) estabelece diferentes desafios ao ordenamento territorial frente à sustentabilidade dos ecossistemas. Especificamente para o centro urbano principal, uma matéria El Ayuntamiento de Almonte presenta más de 50 proyectos al segundo Plan de Desarrollo Sostenible de Doñana, do Jornal online Huvelva24.com, traz em sua edição do dia 22 de fevereiro a seguinte projeção:

Volviendo a Almonte, se han solicitado otras iniciativas de carácter urbanístico. Sobresalen la reurbanización y adecuación de la Plaza Virgen del Rocío, para adaptarla a las Venidas de la Virgen (500.000 euros), así como el proyecto turístico denominado 'Recorrido de la Pastora' (70.000 euros); la mejora de la movilidad urbana en diferentes zonas: Carretera del Rocío (450.000 euros), Chaparral (500.000 euros) y Ciecema (400.000 euros). Finalmente, la mejora de la permeabilidad y accesibilidad al casco urbano en Almonte (200.000 euros).

A projeção de investimentos representa certo consenso a respeito da interdependência agropecuária, cultural e turística que centraliza os rumos do desenvolvimento econômico do município onubense. Por esta razão, a permanência da Virgem do Rocio, durante nove meses consecutivos na cidade representa um afluxo expressivo de visitantes e eventos, facilitando a visibilidade empresarial em tempos de aguda crise econômica e desemprego alarmante. Especialmente na inserção da população jovem (de 16 a 25 anos), cuja cifra de desemprego atingiu 62\% em março de 2014 (conforme dados disponibilizados pelo site http://www.datamacro.com); o que representa quase o dobro da cifra já assustadora da Comunidade Autônoma de Andaluzia: 34,9\% - a maior de toda Espanha.

É nessa conjuntura que um evento tão especial como o Traslado da Virgem do Rocío, em ano marcado pelo Jubileu Canônico em homenagem ao Bicentenário do Rocio Chico, posiciona-se no âmbito das representações de investimento político e compensação econômica. O que também se reflete na postura pedagógica das escolas envolvidas no estudo - os Institutos de Educação Secundária (IES) "Donaña" e "La Ribera" - disponibilizando sua documentação básica e espaços de aula para a sondagem que organizamos aqui. Ambos os institutos são vizinhos a saída norte da cidade que, por intermédio da Avenida de La Juventude e da Rua Che Guevara, permite acesso a Rodovia A-483 (principal ligação com as cidades de Huelva e Sevilha). No sentido sul, seja pelo centro da cidade, seja pela rodovia, alcança-se a Aldeia do Rocio (a $15 \mathrm{~km}$ ) e o Balneário de Matalascañas (a $30 \mathrm{~km}$ ). Por isso a localização das escolas envolve tanto o atendimento local quanto o acesso regional de estudantes de outras cercanias urbanas e rurais.

A IES “Doñana” (http://www.juntadeandalucia.es/averroes/centros-tic/21700654/ helvia/sitio/) tornou-se uma referência plenamente regional, pois além da educação regular secundária, envolve também o curso preparatório para acesso ao nível superior (Bachillerato) e classes especiais com ensino bilíngue (castelhano/inglês). Trata-se de uma estrutura escolar muito bem consolidada, com instalações relativamente bem conservadas e diversificadas, voltadas ao atendimento de aproximadamente 1100 alunos. E a IES "La Ribera" (http://lariberacoeducacion.blogspot.com.br/), mais nova e menor, atendendo um público de aproximadamente 450 alunos, está diretamente voltada ao ensino médio, absorvendo estudantes de duas escolas primárias locais, com um perfil estrutural e socioeconômico mais limitado. Ambas, porém, são marcadas por duas inserções sociais de forte relevância cultural, quando nos detemos a investigar a relação dos sujeitos escolares (alunos 
e professores) com valorização da cidade em festa. Ali está matriculado um expressivo número de estrangeiros e descendentes de imigrantes (africanos, latino-americanos, europeus orientais), demonstrando a forte preocupação com a estruturação de projetos técnicos de inclusão social. Por outro lado, há também, a percepção da interdependência entre o calendário escolar e os múltiplos eventos da festividade rocieira.

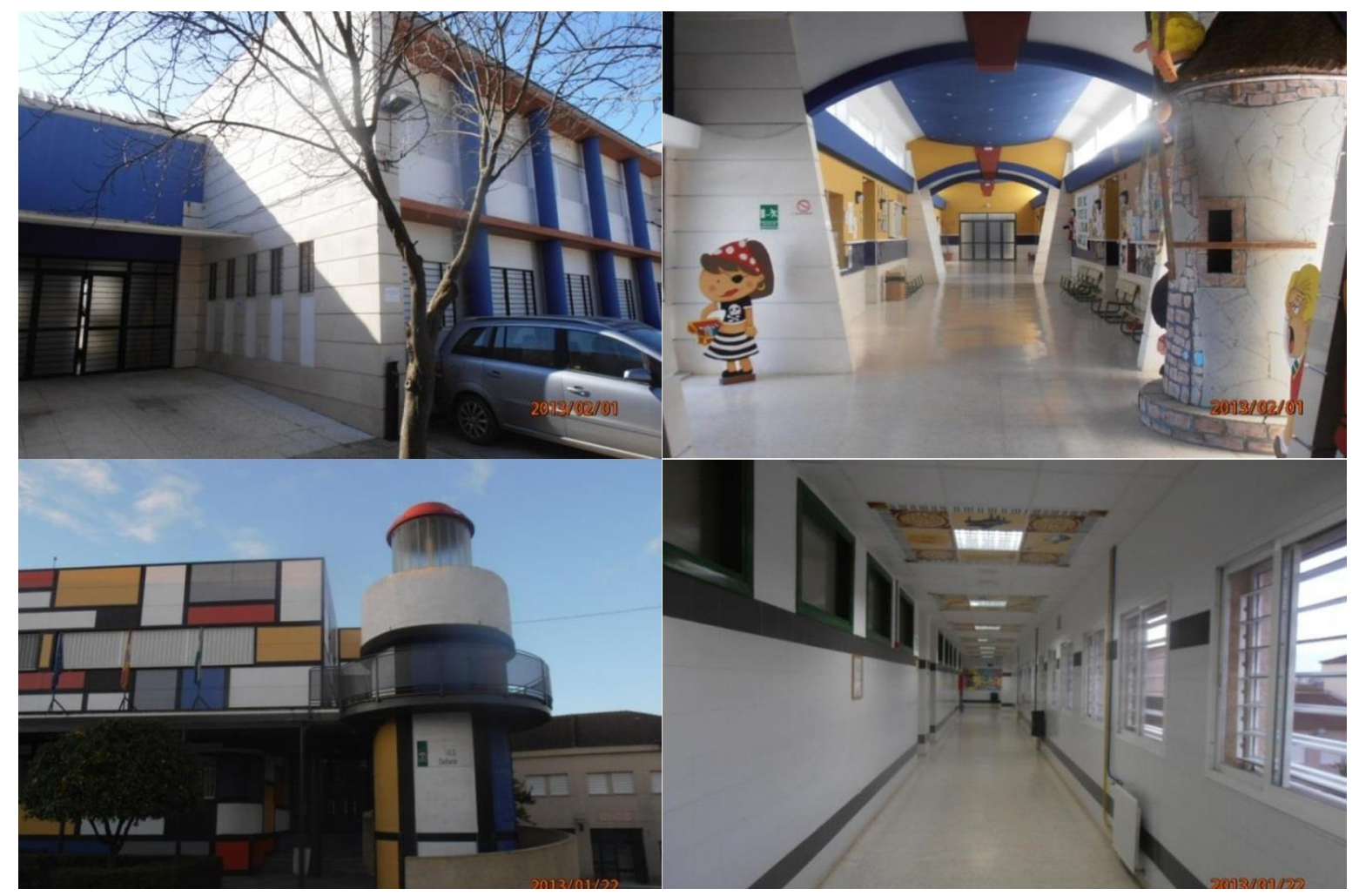

Figura 2 - Imagens dos Institutos visitados e pesquisados: La Ribera (acima); Doñana (abaixo) Fonte: Fotografias do acervo do autor (2013)

\section{CAMINHOS METODOLÓGICOS}

O acesso empírico a realidade geográfica da província de Huelva e da cidade de Almonte deu-se entre 08/01 e 07/02 de 2013, desenvolvendo a etapa de campo do estudo "Turismo e Patrimônio Geoeducacional" (financiado pela Fundação Carolina de Madrid-Espanha). O contato direto com a Faculdade de Educação da Universidade de Huelva (UHU) direcionava-se à busca de fundamentos capazes de intercalar visões da Educação Patrimonial, do Turismo Religioso e da teoria das representações sociais (SÁ, 2002). O objetivo foi dar suporte ao recolhimento de informações escritas, de professores e alunos, dos Institutos de Educação Secundaria (IES), na cidade de Almonte (Huelva).

O estudo de campo, portanto, durante os 30 dias dessa estada, vinculou um trabalho permanente de presença e vivência cotidiana nos gabinetes e biblioteca do Campus El Carmen, da UHU, de um lado; e um total de 5 viagens (2 com pernoites) para contatos, reuniões e execução de questionários, em Almonte (cidade a $60 \mathrm{~km}$ da sede da Província), de outro. Esse processo alternado permitiu-nos compreender as dificuldades latentes para absorver informações sobre um evento, que não tinha por foco de leitura sua ocorrência cultural ou empresarial, mas a representação do mesmo no âmbito educativo. Âmbito este apontado como "desafiador" pelos próprios investigadores com os quais trabalhamos em parceria: os professores Jesus Estepa Gimenez e José María Cuenca López. Suas atuais pesquisas centram-se, respectivamente, no plano das representações curriculares do ensino médio (secundário) e do ordenamento do patrimônio cultural material em arquivos e museus (CUENCA LÓPEZ, 2002; MARTÍN CÁCERES, 2012). O que tornava o enfoque do patrimônio intangível (festas da religiosidade popular), uma contribuição diferenciada às reflexões sobre os 
vínculos escolares com tais bens culturais. A realização desse percurso metodológico envolveu 4 fases, sendo 3 empíricas e 1 complementar:

- Fase 1: Contatos preliminares em Almonte, para formatação final das categorias de análise e composição dos questionários aos discentes.

- Fase 2: Delimitação das estratégias nas Escolas (La Ribeira e Doñana), com aplicação dos questionários e delimitação do grupo de professores para a consulta docente.

- Fase 3: Reelaboração das questões centrais - tendo em vista as categorias - e aplicação das mesmas junto aos docentes; em conjunto com o acompanhamento da dinâmica das atividades festivas na cidade, aproveitando as visitas de campo.

- Fase 4 (Complementar): Depoimentos de estudantes envolvidos do encerramento das festividades do Traslado e registro impresso de notícias nos principais veículos jornalísticos.

Consolidadas essas fases, procuramos retornar à equipe de professores, agendando uma reunião de encerramento do estudo empírico, com o que foi recolhido. Nesta ocasião, repassou-se aos professores Jesus Estepa e José Cuenca (tutores) uma listagem de itens que resumia a documentação reunida no período. A mesma que, no retorno ao Brasil, nos serviria de apoio à análise desse período de campo (vide quadro 1). Também ficaram registradas as demandas para o período de maio/2013, quando a realização das últimas celebrações do Traslado da Imagem da Virgem, em Almonte, envolveriam alguma forma de intercâmbio com as Escolas, indicando assim o momento em que concluiríamos todas as etapas da pesquisa. Recebemos então dos professores Victor Bocanegra (Chefe de Departamento de Geografia e História da IES Doñana) e María Jesús Gómez Soldado (Directora do IES La Ribera) meia dúzia de formulários representativos da última consulta feita com alunos que participaram diretamente do traslado final da Virgem a Aldeia. A seguir (Quadro 1) os itens que compuseram a documentação recolhida nas quatro fases.

Quadro 1 - Atividade e Produtos da Pesquisa

\begin{tabular}{|c|c|c|}
\hline Fases & Atividades Desenvolvidas & Documentos recolhidos \\
\hline 01 & $\begin{array}{c}\text { Reuniões de trabalhos para elaboração dos questio- } \\
\text { nários discentes }\end{array}$ & $\begin{array}{l}\text { Carta de apresentação e autorização para acesso às duas Escolas Secundárias } \\
\qquad \text { - Prazo de aplicação dos questionários }\end{array}$ \\
\hline 01 & $\begin{array}{l}\text { Acesso à biblioteca central do Campus El Carmen } \\
\text { e ao sistema de consultas on-line }\end{array}$ & $\begin{array}{l}\text { Empréstimo de dois lotes de livros para subsídio dos estudos teóricos (rela- } \\
\text { cionados mais adiantes) }\end{array}$ \\
\hline 02 & $\begin{array}{l}\text { Visitas técnicas ao Município de Almonte e as duas } \\
\text { IES pesquisadas. }\end{array}$ & $\begin{array}{l}\text { Recolhimento de } 149 \text { questionários, no } 3^{\circ} \text { e } 4^{\circ} \text { anos da Secundária e } 2^{\circ} \text { ano } \\
\text { do Bachillerato. Entrevistas institucionais. }\end{array}$ \\
\hline 02 & $\begin{array}{l}\text { Acompanhamento dos festejos: Visita da Irmanda- } \\
\text { de de Triana em Almonte }\end{array}$ & $\begin{array}{l}\text { Fotos e informações da imprensa, destacando a interação turismo religioso e } \\
\text { o calendário dos eventos urbanos. }\end{array}$ \\
\hline 03 & $\begin{array}{l}\text { Sistematização dos formulários de entrevistas aos } \\
\text { professores }\end{array}$ & $\begin{array}{l}\text { Aplicação e recolhimento dos } 5 \text { formulários aos docentes em reuniões nas } \\
\qquad \text { IES - Agenda de tarefas para Maio/2013 }\end{array}$ \\
\hline 03 & $\begin{array}{l}\text { Feira Internacional de Turismo de Madrid; roteiros } \\
\text { de visita em cidades fronteiriças. }\end{array}$ & $\begin{array}{l}\text { Folhetos com ênfase em roteiros, europeus e espanhóis, do turismo religioso. } \\
\text { Registros fotográficos. }\end{array}$ \\
\hline 04 & $\begin{array}{l}\text { Acompanhamento de Notícias até o retorno do } \\
\text { Traslado a Aldeia }\end{array}$ & $\begin{array}{c}\text { Notícias do Jornal online www.huelvainformación.es, mais } 6 \text { formulários de } \\
\text { alunos que participaram do traslado final. }\end{array}$ \\
\hline
\end{tabular}

Fonte: Elaboração própria (2014)

\section{AS REPRESENTAÇÕES ESCOLARES DO TRASLADO}

Considerando as fases apontadas no quadro anterior, procuramos aqui desenvolver o detalhamento dos resultados tendo em vista as três fontes que privilegiamos na consulta empírica sobre o Traslado da Virgem entre El Rocio e Almonte, no Bicentenário do Rocio Chico (2012/2013). 


\section{A Visão Docente}

A visão docente sobre as representações da Educação Patrimonial, especialmente centradas na Vicência do Traslado da Virgem, demonstrou as dimensões limites da Questão Patrimonial na Educação Básica. Se de um lado existe um empenho efetivo e construtivo em incentivar uma aprendizagem contextualizada dos conteúdos científicos e modernos; de outro, persiste a desconfiança estrutural sobre a margem de concessão cultural que pode ou deve ser dada à reprodução das tradições, dos costumes e das práticas festivas, tão amarradas que são ao âmbito religioso; e, portanto, tão apartado dos parâmetros do conhecimento científico. No fundo, os cinco professores que entrevistamos demonstraram pouquíssima objeção em trabalhar suas disciplinas (história e geografia) reconhecendo a expressividade cultural das festas andaluzas na comunidade escolar de Almonte. Mas nem por isso afirmaram uma disposição em centrar seus respectivos trabalhos na referencia eventual ou permanente deste fenômeno patrimonial.

Vejamos como as questões formuladas aos docentes foram resolvidas:

Das cinco entrevistas buscamos selecionar uma que melhor representasse a forma de vínculo predominantes dos educadores com os Institutos. Em nenhum deles - como o que apresentamos no exemplo de abaixo - o Traslado e a presença da Santa na cidade, ganhava justificativa para uma programação diferenciada no Departamento de Ciências Humanas.

Quadro 2 - Entrevista Docente

\begin{tabular}{|c|c|}
\hline Focos de Interesse e Questões Formuladas & Exemplos de Respostas predominantes. \\
\hline $\begin{array}{l}\text { Sofre formação docente. Como se deu sua forma- } \\
\text { ção em Ciências Humanas e sua trajetória como } \\
\text { professor(a)? }\end{array}$ & Historia. \\
\hline $\begin{array}{l}\text { Sobre a Valorização cultural e educativa das Festas. } \\
\text { O que pensas da Festa (festividades populares) como } \\
\text { fato cultural? }\end{array}$ & $\begin{array}{l}\text { Son una importante seña de identidad en España aunque no siempre estoy de acuer- } \\
\text { do en seguir con continidad de todas ellas, muy especialmente aquellas que suponen } \\
\text { un maltrato animal. }\end{array}$ \\
\hline $\begin{array}{l}\text { Sobre a Festa do Traslado da Virgem, especificamen- } \\
\text { te. O que pode destacar do Traslado da Virgem do } \\
\text { Rocio conforme sua vivência e informações? }\end{array}$ & $\begin{array}{l}\text { No la vivo porque no soy de la zona pero, dado que supone un hecho importante } \\
\text { para el conjunto de la población almonteña, me parece importante esta Venida de la } \\
\text { Virgen. Para el pueblo almonteño es su seña de identidad más importante y, econó- } \\
\text { micamente, es Fundamental }\end{array}$ \\
\hline $\begin{array}{l}\text { Sobre as Festas nos Conteúdos Curriculares. De } \\
\text { que maneira as festas deveriam ser trabalhadas nas } \\
\text { aulas? Em seu entendimento os trabalhos ou aulas de } \\
\text { campo poderiam auxiliar? }\end{array}$ & $\begin{array}{l}\text { No necesariamente. En el caso del Rocío no lo veo necesario. Ellos participan de } \\
\qquad \text { ella. Continuamente. }\end{array}$ \\
\hline $\begin{array}{l}\text { Sobre fontes e expectativas como esse evento. } \\
\text { Quais são as fontes de informação ao que tens sobre } \\
\text { o traslado da Virgem? Gostarias de saber mais sobre } \\
\text { o evento? Sim ou não e por quê? }\end{array}$ & $\begin{array}{l}\text { El propio alumnado. No especialmente. No me siento identificada con él y creo que } \\
\text { el alumnado le da demasiada importancia. Creo que ignoran otras muchas manifes- } \\
\text { taciones culturales de su entorno y fuera de él porque piensan que tienen lo mejor y } \\
\text { que no hay ninguna que pueda superarla. }\end{array}$ \\
\hline $\begin{array}{c}\text { Sobre a percepção do patrimônio cultural no ensino. } \\
\text { Entendes o patrimônio cultural imaterial como um } \\
\text { bom desafio para o ensino na atualidade? Sim ou } \\
\text { Não? Justifique. }\end{array}$ & $\begin{array}{c}\text { Si, si se trabajan todo tipo de manifestaciones y no exclusivamente las del entorno. } \\
\text { Trabajar exclusivamente estas radicaliza las formas de pensar. }\end{array}$ \\
\hline
\end{tabular}

Fonte: Elaboração própria (2014)

Em geral o que se manifesta no discurso docente, esteja ele redigido ou falado, é o reconhecimento de uma contradição sem condições de superação. Se de um lado, o traslado, pedagógica e existencialmente não faz parte dos valores docentes, de outro não há uma justificativa maior para a incorporação deste tema específico na pauta dos trabalhos educativos. Como afirma a professora selecionada aqui para representar o pensamento de seus colegas, nos dois institutos: "Não me sinto com ele [o evento] e creio que o alunado lhe dá demasiada importancia". Portanto, o destaque para a importância discente ao cotidiano dos festejos - e sua consequente valorização patrimonial - não se incorpora como um problema educativo "positivo"; isto é, não impulsiona a construção temática e conceitual do trabalho escolar. Ao contrário, tende mesmo a cercear a amplitude e diversidade 
de visões que pauta a formação escolar. Daí sua finalização da entrevista, assim como de outros educadores, ser sinalizadora dos cuidados devidos com a educação patrimonial: Trabalhar exclusivamente esta [festa, traslado] radicaliza as formas de pensar.

Foi oportuno receber da mesma docente, meses depois da entrevista (em Maio de 2013), um conjunto de quatro formulários preenchidos por quatro alunos que apontavam seu franco envolvimento com a finalização do Traslado: a volta da Virgem do Rocio a sua aldeia santuário. Ao todo foram seis formulários retornados dos dois institutos, atendendo a um pedido do pesquisador que não poderia acompanhar os momentos decisivos do encerramento dos festejos. Um deles, estudante estrangeiro (romeno de nascimento), apontava em sua justificativa de participação uma dimensão relativamente ignorada no processo de valorização contemporânea das festas populares; e de sua franca patrimonialização. Ao responder a questão da vivência pessoal na procissão de encerramento dos festejos, forneceu um indicativo contra a possível radicalização da festa: podia ali viver o Rocio como mais um crente e não como alguém estranho ou novo. O traslado me integrou melhor com vizinhos e amigos. Neste sentido é que a visão docente acaba operando uma "preocupação exagerada" como o peso universalizado dos conteúdos escolares previstos e ignorando recomendações cada vez mais explicitas na farta documentação pedagógica produzida e disponibilizada. Se o patrimônio cultural, especialmente em suas práticas "imateriais", serve como ponto de partida (embasamento) à reconstrução e mobilização das competências educativas e sociais (PERRENOUD, 1999), resta-nos um desafio para discussão posterior: por que os docentes ainda temem lidar com a "matéria-prima" de sua produção de saberes? E quando esta "matéria" é plenamente contextualizada, porque o temor atinge níveis de indisfarçável distanciamento?

Antes desse debate central, impossível de avançar sem a lapidação do conceito de geoeducação, visitemos a leitura discente e a composição midiática emergente da festividade aqui trabalhada.

\section{A Leitura Discente}

Também é oportuno frisar que os dias de aplicação e recolhimento foram distintos, atendendo por orientação aos docentes a melhor oportunidade para evitar sobreposição de tarefas. Será descrito, a seguir, os principais aspectos resultantes das 12 indagações, sistematizadas no modelo padrão dos questionários.

Quadro 3 - Distribuição dos alunos entrevistados

\begin{tabular}{|r|c|c|c|c|c|c|c|}
\hline Escola (IES) & Ano & $\mathrm{N}^{\mathrm{o}}$ de alunos & Ano & $\mathrm{N}^{\mathrm{o}}$ de alunos & Ano & $\mathrm{N}^{\text {o de alunos }}$ & Total \\
\hline LA RIBERA & $3^{\circ}$ & 42 & $4^{\circ}$ & 36 & $5^{\circ}$ & 00 & 78 \\
\hline DOÑANA & $3^{\circ}$ & 13 & $4^{\circ}$ & 38 & $5^{\circ}$ & 20 & 71 \\
\hline Questionários & & & & & & & 149 \\
\hline
\end{tabular}

Fonte: Elaboração própria com base na pesquisa de campo (2014)

A primeira questão versou sobre quais seriam os valores (atributos significativos) mais importantes em suas festas populares. Nesse quesito, os alunos dos 3 anos consultados deram aos aspectos "tradicional", "religioso" e "antigo" como os mais importantes. Os demais itens variaram bastante, conforme cada turma. Os $3^{\circ}$ anos, de Doñana de La Ribera e o $5^{\circ}$ ano (conhecido como bacchillerato e equivalente ao pré-vestibular) de Doñana, elegeram também o aspecto "econômico" como principal valor da festa. Já para o $4^{\circ}$ ano há mais diversificação. O aspecto "espetacular" marca a segunda opção de Doñana; enquanto em La Ribera foi o atributo "natural" que alcançou quantidade similar.

Ao serem perguntados, na questão seguinte, sobre o que ensinariam da sua região a um estrangeiro - por proximidade, a questão fez menção a "um amigo de Madrid" - os alunos dos três anos consultados deram destaque a dois tópicos: o Parque Nacional de Doñana, pela importância de preservação ambiental, e a Igreja Matriz de Nossa Senhora da Assunção na praça central da cidade, por abrigar na ocasião a Virgem do Rocio. 
A indagação seguinte também solicitava exemplos de sugestões abertas. Pedia informações sobre festas andaluzas, fora de Almonte, também significativas para visitar. Embora tivessem mencionado outros povoados da região, houve um número maior de respostas em branco ou indicações isoladas sem uma justificativa apontada. Foram listados nove festejos mais mencionados. Observa-se o predomínio de dois vínculos diretos com a devoção do Rocio: festas que antecedem Pentecostes e motivações religiosas.

Quadro 4 - Festas que antecedem Pentecostes

\begin{tabular}{|c|c|}
\hline EVENTO & Endereço virtual das informações sobre o evento \\
\hline 1.Carnaval na Praia de Matalascañas & (https://www.youtube.com/watch?v=523gZYX3dVM), \\
\hline 2.Feira de Sevilha & (https://www.youtube.com/watch?v=TG1uM019D3g) \\
\hline 3.Feira de Córdoba & (https://www.youtube.com/watch?v=qBWD46VBFjA ), \\
\hline 4.Semana Santa de Sevilla & (https://www.youtube.com/watch?v=mIEullth6Vs), \\
\hline 5.Carnaval de Cádiz & (https://www.youtube.com/watch?v=mIEuIlth6Vs), \\
\hline 6.Cruzes de Maio de Rociana & (https://www.youtube.com/watch?v=dyhAxowtWTk), \\
\hline 7.Cruzes de La Palma Par del Condato & https://www.youtube.com/watch?v=DBzGjIwuWeU ), \\
\hline 8.Colombinas ou Feira de Huelva & (https://www.youtube.com/watch?v=w6n34bwN-GQ) \\
\hline 9.Gamonitas de Bollullos & (https://www.youtube.com/watch?v=vfefLTULlv8) \\
\hline
\end{tabular}

Fonte: Elaboração própria (2014)

Já quando se apontam sete exemplos de festividades típicas em Almonte, a maior parte das respostas obtidas indicam reconhecimento e significativa participação em 2 ou 3 delas. São, especialmente mencionadas: O Rocio Grande, O Rocio Chico e o Traslado da Virgem do Rocio. Em contrapartida, houve um expressivo número de menções sobre o desconhecimento de outra festa religiosa muito próxima ao encerramento do período pascal, e que tem especial presença em Almonte: a festa de Corpus Christi. A questão seguinte, por sua vez solicitava uma escolha, baseada na indagação anterior, sobre qual das festas eles mais gostavam e qual aspecto mais valorizam nas que escolheram. As respostas obtidas deram maior destaque ao Traslado da Virgem do Rocio, sendo seguida pelo Rocio Grande de Pentecostes e o Rocio Chico. O que de um lado demonstra a afirmação de uma hierarquia do conjunto de festividades rocieiras, posicionado a partir da centralidade festiva do próprio município. Ainda que as duas últimas festas sejam anuais e o Traslado um evento bem mais extraordinário.

Quanto a sexta questão, dirigida especificamente para uma avaliação mais criteriosa dos aspectos positivos e negativos do Traslado da Virgem, ficou exposto certo equilíbrio entre os valores e as preocupações ligadas o evento. Algumas ideias são reproduções do que ouviram falar a respeito; outras menções denotam observações muito diretas do que vinha ocorrendo na cidade, nos últimos meses; além de expectativas para o largo período em que a santa permanecerá em Almonte. Para indicar aspectos positivos e negativos da Venida de La Virgen, os pesquisados indicaram:

Quadro 5 - Sistematização das respostas a $6^{\mathrm{a}}$ questão

\begin{tabular}{|c|c|}
\hline ASPECTOS POSITIVOS & ASPECTOS NEGATIVOS \\
\hline Mantém a tradição & O caminho é muito longo e cansativo. \\
\hline O ato de sua vinda e a possibilidade de tocá-la & Há grosseria nas ruas (aumento de acidentes) \\
\hline A possibilidade de conhecer novas pessoas & Muito barulho. Há muitos estrangeiros (muita gente) \\
\hline O aumento na economia (turismo) & Há uma má gerência da economia \\
\hline Os sentimentos religiosos (fé, devoção) & Há tumulto em volta da virgem \\
\hline Laços familiares e amistosos são revigorados & Existem poucos estacionamentos \\
\hline Empatia dos participantes & O trânsito fica congestionado \\
\hline A festa em si e sua representação na região & Há casos de que se tem que pagar para tocar a virgem \\
\hline
\end{tabular}

Fonte: Elaboração própria a partir da pesquisa de campo (2014) 
A questão seguinte procurou direcionar alternativas de participação em algum festejo da Comunidade Andaluza, limitando quatro tipos de alternativas: não participou; sim participou pela tv ou internet; sim participou em períodos de férias e sim, tem participado todos os anos. As respostas obtidas foram contabilizadas no quadro a seguir:

Quadro 6- sistematização das respostas a $7^{\mathrm{a}}$ questão

\begin{tabular}{|c|c|c|c|c|c|c|c|}
\hline Instituto e Ano & $3^{\circ}$ Ano (13) & $4^{\circ}$ Ano (38) & $2^{\circ}$ Bach.(20) & $3^{\circ}$ Ano (42) & $4^{\circ}$ Ano (36) & \multicolumn{2}{|c|}{ TOTAL } \\
\hline Não participou/não se recorda & 03 & 17 & 05 & 26 & 19 & 70 & $47 \%$ \\
\hline Sim, participou pela mídia & 02 & 02 & 00 & 06 & 05 & 15 & \\
\hline Sim, participou nas férias & 00 & 03 & 03 & 01 & 07 & 14 & \\
\hline Sim, participa todos os anos & 07 & 09 & 12 & 06 & 02 & 36 & $43 \%$ \\
\hline Não responderam & 01 & 07 & 00 & 03 & 03 & 14 & $9 \%$ \\
\hline
\end{tabular}

Fonte: Elaboração própria a partir da pesquisa de campo (2014)

Conforme pode ser atestado no quadro a não participação (ou memória do envolvimento) na festa é ligeiramente predominante no conjunto de 149 entrevistados. O que denota um relativo distanciamento da comunidade discente frente à diversidade festiva da região. A necessidade de indicar uma festa como exemplo talvez tenha colaborado com o número proporcionalmente alto dos que não responderam.

O questionamento seguinte, centrado na existência da temática "festas" (de Almonte ou Andaluzas) no currículo escolar, teve um significativo predomínio da resposta "não estudou", seguida da justificativa: porque não faz falta. Apenas com o $3^{\circ}$ ano do Instituto La Ribeira e o $2^{\circ}$ Bacchilerato, ocorreu um destaque inverso para o "sim, já estudou". Nesse caso a maior parte das indicações de disciplinas recaiu nas aulas de Religião (ministradas em ambos os institutos).

O questionamento seguinte foi direcionado para utilidade pedagógica (em termos de aprendizagem discente) de uma visita escolar a uma dessas festas. A ideia era colher percepções dos alunos entre os vínculos da festa com a prática de campo. O "sim", como afirmação de vínculo, transpareceu em quase todas as respostas, variando apenas em justificativas conforme as turmas e escolas. No Instituto La Ribera disseram é possível e aprenderiam mais coisas novas sobre a cultura. Apenas 14 responderam negativamente. Já no IES Doñana, o predomínio sim, pela mesma razão, refluiu um pouco, tendo em vista que apenas no bacchilerato cerca de 1/3 respondeu "não".

Ao serem perguntados sobre quais as principais fontes de onde recebem informações sobre o Traslado e outras Festas Andaluzas ficou bastante destacado, em ambos os Institutos a proximidade interpessoal dessas fontes. As informações chegam predominantemente por intermédio dos familiares, vizinhos e amigos. Depois ainda é relevante os meios de comunicação, como TV e Internet. E em terceiro lugar a vivência direta das festas como participante.

Quando nos referimos aos possíveis impactos que o Traslado traz para Almonte, as respostam mais ressaltadas - em uma proporção de $90 \%$ das que foram assinaladas - indicaram o papel positivo desses impactos. Na economia, no turismo receptivo, no reconhecimento dos valores urbanos para a cultura rocieira. O que evidenciou também que a opção contrária (negando o impacto ou sua positividade) teve mais relação com o não entendimento da pergunta ou a indisposição em respondê-la.

E finalizando, a última questão procurou explorar a visão de futuro dos estudantes a respeito das potencialidades locais, frente ao futuro da festa (no caso o próximo Traslado previsto para 2019). As respostas destacaram o que eles poderiam propor às Instituições (em geral) para melhorar na realidade da festa em relação à cidade e aos participantes. Assim foram sugeridos os seguintes pontos: maior segurança e assistência médica; organização melhor orientada ao estabelecimento de regras na participação dos estrangeiros (referindo-se ao maior controle na aproximação dos não 
devotos a Santa); promoção de shows beneficentes e atividades educativas para os jovens, aproveitando mais o período da estada da Santa; melhoria da decoração das ruas de maneira a atender moradores e participantes; aumento planejado do espaço de estacionamentos; mudança de datas e motivações visando diminuir a periodicidade da visita; mais barateamento dos preços dos produtos.

Essa tabulação de respostas discentes mais relevantes não teve a finalidade exclusiva de demonstrar um contraste com o pensamento docente, na representação escolar do contexto festivo. Cumpriu, acima disto, uma função rastreadora da interface entre o reconhecimento da comunidade estudantil sobre as limitadas relações da escola com o patrimônio imaterial; seja ele o traslado ou outros eventos culturais marcantes em Andaluzia.

\section{A Projeção Midiática dos Lugares Referência do Traslado}

A terceira leitura das representações, pertinente a discussão proposta, diz respeito à forma de condução midiática da visibilidade regional do evento. Escolhemos o periódico online "Huelva Información" (http://www.huelvainformacion.es/), como base de coleta das principais notícias diretamente ligadas à cidade de "Almonte" - palavra de busca no banco de dados do jornal - e aos acontecimentos do Traslado. O Quadro 7 nos permite reunir e observar um conjunto de 54 notícias, coletadas entre Agosto de 2012 a Junho de 2013.

O primeiro grupo coletado dizia respeito aos acontecimentos diretamente ligados a ação da Irmandade Matriz de Almonte, organização responsável por todo processo de preparação, realização e retorno da Virgem, durante às festividades do Traslado no Ano Jubileu Mariano. Aqui agrupamos 22 matérias classificadas (Quadro 6) no vínculo "central”; isto é, seu conteúdo veiculava a expressividade maior das práticas devocionais que ocupam as tradições entre o Rocio Pequeno ("Chico"), em Agosto e o Rocio Grande, na celebração de Pentecostes (Maio/Junho). As entrevistas apontadas, na sequência, correspondem as falas de dois importantes representantes gestores da devoção central: uma do padre jesuíta José Gonzáles Quevedo, destacando as fortes mudanças na cultura rocieira, sem enfraquecer, contudo, a intensidade da fé. Quevedo foi reconhecido como Poeta da Virgem, recebendo o título de "Hermano honorário" da Irmandade. A outra entrevista trás o discurso do atual prefeito de Almonte José Antonio Dominguez, pelo PP (Partido Popular). 
Geoeducação das Representações Religiosas

Quadro 7 - Listagem de Notícias

\begin{tabular}{|c|c|c|}
\hline DATA $\mathbf{m} / \mathbf{d} / \mathbf{a}$ & $\begin{array}{c}\text { Vinculo da No- } \\
\text { tícia } \\
\end{array}$ & Título ou Manchete da Notícia Coletada \\
\hline $12 / 08 / 12$ & Central & El Rocío se viste de pasión \\
\hline $08 / 13 / 12$ & Central & Semana grande en Almonte \\
\hline $08 / 20 / 12$ & Central & El obispo invita a revivir la fe almonteña de 1813 \\
\hline $08 / 21 / 12$ & Central & Un acontecimiento sin precedentes \\
\hline $08 / 31 / 12$ & Central & La ofrenda a la Virgen desata una ola de solidaridad \\
\hline $16 / 09 / 12$ & Central & El Patronato de Turismo lleva el Año Jubilar Mariano a un salón especializado \\
\hline $09 / 18 / 12$ & Central & Comienza el desmontaje de la catedral instalada para la Venida \\
\hline $10 / 25 / 12$ & Central & La Virgen del Rocío ya luce su traje de reina en la Asunción \\
\hline $10 / 28 / 12$ & Central & La hermandad presenta el libro del bicentenario del Rocío Chico \\
\hline $08 / 12 / 12$ & Central & Semana histórica en Almonte \\
\hline $01 / 16 / 13$ & Central & Junta y hermandades concretan las líneas del Plan Romero \\
\hline $02 / 20 / 13$ & Central & La Comisión del Rocío Jubilar aprueba las normas de funcionamiento \\
\hline $02 / 24 / 13$ & Central & San Juan del Puerto peregrina en su centenario \\
\hline $02 / 26 / 13$ & Central & La Hermandad del Gran Poder dona el pañito para el traslado de la Virgen a la aldea \\
\hline $02 / 04 / 13$ & Central & Multitudinario 'bautismo' rociero en Año Jubilar \\
\hline $04 / 04 / 13$ & Central & Comienzan los trabajos para volver a instalar la catedral gótica efímera \\
\hline $04 / 28 / 13$ & Central & Almonte ya espera el salto a la reja \\
\hline $05 / 05 / 13$ & Central & La Hermandad Matriz aspira a un nuevo Año Jubilar en 2019 \\
\hline $02 / 07 / 13$ & Central & Cumbre episcopal ante la Virgen del Rocío \\
\hline $09 / 17 / 13$ & Central & Comienza la peregrinación rociera \\
\hline $10 / 10 / 13$ & Central & Una magna exposición cofrade reunirá enseres de 24 hermandades andaluzas \\
\hline $08 / 11 / 13$ & Central & La Hermandad Matriz abre un punto de información para los peregrinos \\
\hline $01 / 26 / 13$ & Entrevista & "Lo único que no ha cambiado en el santuario del Rocío es la fe" \\
\hline $03 / 28 / 13$ & Entrevista & "El Año Jubilar es un proyecto que se mantendrá en el tiempo" \\
\hline $09 / 02 / 12$ & Indireto & Los alcaldes del Condado intentan aprovechar el tirón del Jubileo \\
\hline $09 / 06 / 12$ & Indireto & La Diputación asegura que colaborará en el Año Jubilar \\
\hline $08 / 21 / 12$ & Indireto & Salud asiste a 239 personas en el traslado de la Virgen del Rocío \\
\hline $08 / 28 / 12$ & Indireto & Los comercios tendrán una marca distintiva de calidad del Año Jubilar \\
\hline $08 / 28 / 12$ & Indireto & PP y PSOE se enzarzan por la limpieza de las calles de El Rocío \\
\hline $08 / 31 / 12$ & Indireto & El PP exige a la Junta y la Diputación que "dejen de ser un obstáculo" para el Año Jubilar \\
\hline $09 / 13 / 12$ & Indireto & La falta de un consorcio sobre el Año Jubilar enfrenta a los partidos \\
\hline $10 / 11 / 12$ & Indireto & El Consorcio del Año Jubilar consigue la unanimidad política \\
\hline $11 / 22 / 12$ & Indireto & El Consistorio pide un plan de seguridad supramunicipal para el Año Jubilar \\
\hline $12 / 21 / 12$ & Indireto & Campanadas con frambuesas \\
\hline $12 / 26 / 12$ & Indireto & El dispositivo de seguridad en Almonte y El Rocío se reforzará con motivo de la Nochevieja \\
\hline $02 / 01 / 13$ & Indireto & Crespo destaca la oportunidad de creación de empleo que supone el Año Jubilar Rociero \\
\hline $01 / 29 / 13$ & Indireto & La Subdelegación critica la ausencia de un plan de tráfico en La Candelaria \\
\hline $03 / 17 / 13$ & Indireto & La aldea tiene más tirón turístico que Almonte \\
\hline $03 / 19 / 13$ & Indireto & Los empresarios no quieren el cierre del antiguo acceso a la aldea \\
\hline $04 / 19 / 13$ & Indireto & El Ayuntamiento pide al SAS dos equipos médicos para cubrir la procesión de la Virgen \\
\hline $04 / 30 / 13$ & Indireto & Las hermandades rocieras ven un peligro la entrada por la variante \\
\hline $11 / 05 / 13$ & Indireto & La Onubense muestra su adhesión al año Jubilar Rociero \\
\hline $06 / 27 / 13$ & Indireto & Un espectáculo en manada \\
\hline $08 / 24 / 13$ & Indireto & La Junta se felicita por la ayuda prestada a Almonte para limpiar la zona de la Venida \\
\hline
\end{tabular}

Fonte: Huelva Información http://www.huelvainformacion.es/ (de Agosto de 2012 a Junho de 2013) 
E finalmente, na Pesquisa, buscamos compreender a importância do encadeamento de projetos de investigação científica em programas de temáticos estruturalmente articulados. Os estudos geoeducacionais que vem conduzindo a amplitude de temas de nosso Laboratório, não tinha estabelecido até aqui uma condição centrífuga (centrada e irradiadora) que servisse de eixo e expansão desses mesmos temas. Daí sentirmos a necessidade da criação de um projeto-macro, com capacidade efetiva de explorar a Comunicação Patrimonial - como campo temático referencial - na construção desse papel. Para tanto, o diálogo aproximativo entre a Geografia e Comunicação, não apenas, tende a incluir as questões educacionais e patrimoniais que problematizamos nestes últimos 7 anos, mas também orientar o reconhecimento acadêmico externos de nosso padrão de estudos. A formulação da questão a seguir pode sintetizar melhor esse padrão: no lugar simbólico investigado, qual a representação comunicada pelo patrimônio? Cada estudo que desenvolvemos no LEGE - e a partir daqui difundiremos em redes comunicacionais - considera a densidade geográfica (geograficidade) do lugar como espelho/expressão de seu simbolismo. Mas o processo conflituoso de uma Educação Patrimonial contemporânea - conforme indicamos no projeto, pensando no Com e no Contra a EP - não permite apenas o reconhecimento desse simbolismo. Exige ações (dialógica e labiríntica) na escolha de patrimônios-chave para a decodificação desse lugar. O que não se faz acolhendo por antecipação o patrimônio imaterial das festas religiosas como modelo excludente. Daí a força comunicacional apontar para o desdobramento da pesquisa, lembrando-os ser este o tempo de abrir o leque continental (ibero-americano ou euro americano) de localidades com as quais possamos organizar uma rede de informações geográficas. Não somente para desenvolver o curso e promover a extensão das publicações desse trabalho; mas também, no estratégico dever de produzir um conjunto de informações e indicadores locais ao planejamento e gestão da educação patrimonial.

\section{A RITUALIDADE FESTIVA NO DESENHO DA GEOEDUCAÇÃO}

A compreensão da festa popular, intermediada pelo "fato memorativo" da manifestação religiosa, induz ao reconhecimento de um processo ritual. Sistema ritual (ou Ritualidade) este, indispensável às formas de identificação e atualização da cultura religiosa na realidade pós-moderna. Sabe-se que os ritos compõem a identificação de uma manifestação cultural específica a ponto de traduzir toda identidade de uma região cultural, uma nação ou um conjunto civilizatório.

Mas é na frequência sistemática de ritos herdados (genética e historicamente) que se estabelece um reconhecimento coletivo capaz de traduzir tal conjunto em uma segurança/conforto cultural. A Ritualidade, portanto, qualifica positivamente a adaptação do rito, da sabedoria de alguns (sacerdotes) a cooperação de todos (participantes e devotos). Resta compreender em que momento tal celebração ritual alcança uma dimensão festiva. E na sequência, capturar, em uma abordagem fenomenológica (tida aqui como intersubjetiva ou relacional) três forças vetoriais do espaço religioso contemporâneo em sua capacidade de representar-se como geoeducativo.

Para avançar na abordagem relacional, que significado pode ser constituído na investigação do espaço religioso pelo conceito de geoeducação? A pesquisa a pouco apresentada nos fornece uma indicação preliminar: geoeducação corresponde ao exercício de envolvimento de uma coletividade, com seu espaço coletivo peculiar (simbólico), visando efetivo aperfeiçoamento da aprendizagem valorativa. Por extensão, tal aperfeiçoamento demanda o equivalente exercício de interpretação espacial do processo educativo. Portanto, a geoeducação é ao mesmo tempo uma prática e um saber contextualizado na ritualização do estar na Terra. Nestes termos, pode-se considerar o Traslado, as Celebrações rocieiras e tantos outros eventos culturais marcantes da Região de Andaluzia, um espaço peculiar, um símbolo aberto ao aperfeiçoamento geoeducacional. Entretanto, para que essa abertura seja promovida do plano objetivo potencial ao nível intersubjetivo relacional - como efetivo projeto de valorização patrimonial nos ritos festivos - torna-se indispensável uma composição vetorial equilibrada; um esquema relacional, que tentamos desenhar na Figura 3. 
Observando a figura, vemos em destaque os triângulos X e Y posicionados em oposição/complementação; como se estivessem em um ambíguo movimento, ao mesmo tempo de aproximação e afastamento para um encaixe futuro. E o que permite a instalação presencial desse "encaixe"? De um lado a ação vetorial dos símbolos que emergem de X para encontrar em Y a virtualidade do Patrimônio Religioso, exposto e aberto à diversidade política das estratégias de acesso geográfico às suas manifestações fixas (memoriais) e fluidas (vias sacras). Para tanto a Imagética comunicativa e a visitação turística corresponde, de maneira cooperada, a condição de categorias sensoriais significativas; e, portanto, a símbolos geoeducacionais de irradiação do que a religiosidade (comunicativa e turística) tende a demarcar no espaço cultural contemporâneo.

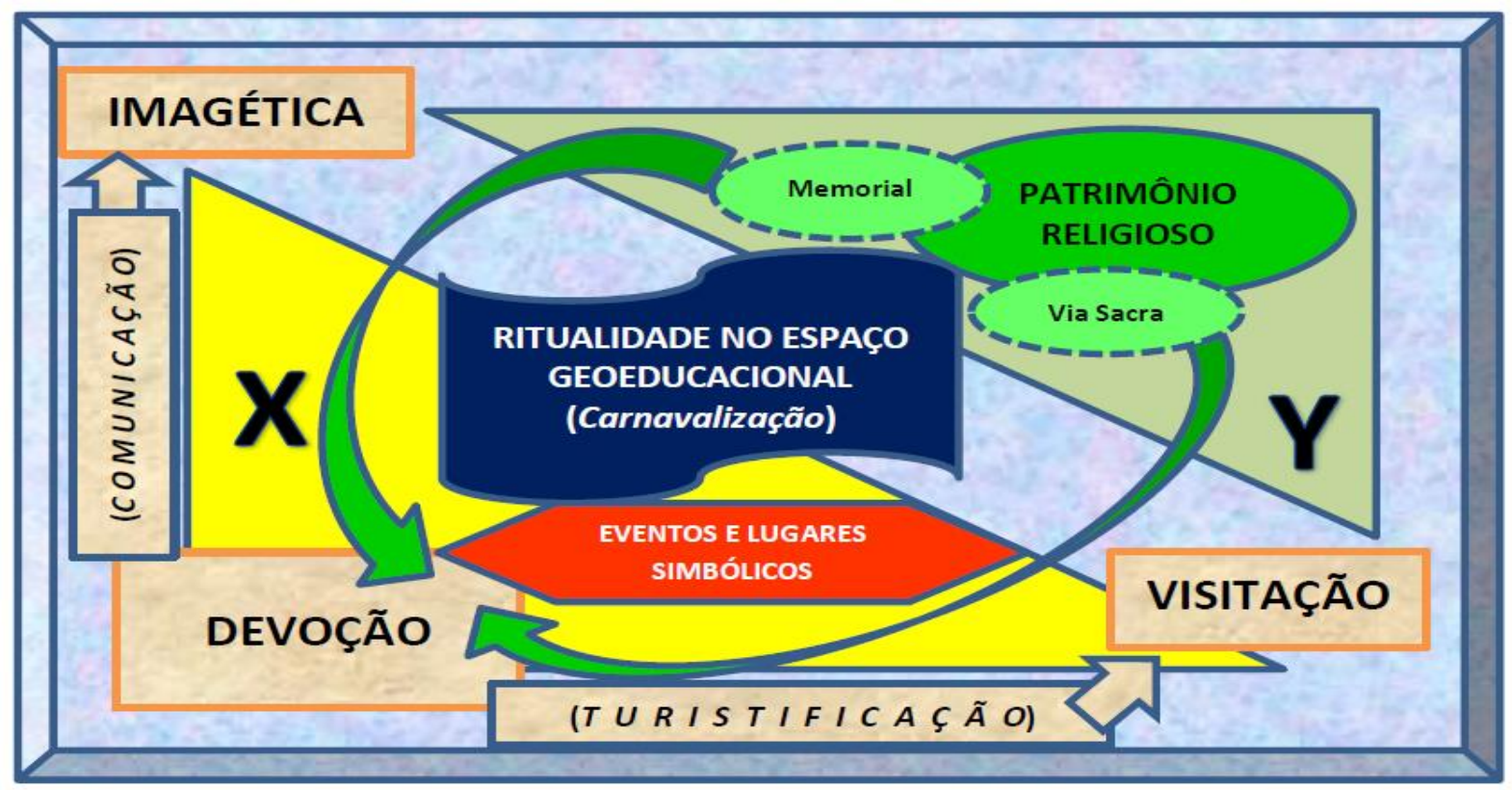

Figura 3 - Estratégia Devocional na Geoeducação - Fonte: Elaboração própria (2014)

Do outro lado, o virtual desse Patrimônio requer mais e mais caminhos envolventes de experimentação. A experiência religiosa farta (leia-se superficial, labiríntica ou profunda) nunca demonstrou tantas possibilidades de habitar o cotidiano dos grupos e indivíduos, mediante a vivência radical da multiplicidade da fé. Um contrato efetivo da racionalidade pós-moderna no sistema de crenças. Neste, tanto a memória quanto o caminho ao sagrado podem implicar o envolvimento direto de participantes externos. Por isso a modelagem dessa terceira categoria simbólica é nomeada pela carnavalização ritual. Ou seja, a ritualidade no espaço Geoeducacional compõe uma mimésis do constante processo civilizatório encarnado pela Festa do Carnaval. Modelo festivo de alta capacidade, até o limiar do Século XX, no enfretamento das questões fundamentalistas emergentes, principalmente, das leituras e valores exclusivistas do monoteísmo.

Assim, a Estratégia Devocional se "fecha" mediante o centralismo que a ritualidade carnavalesca tende demarcar. Seja no espaço ilimitado dos valores devocionais, cada vez mais racionalizados; seja na eventualidade simbólica de festas extraordinárias e alegorias patrimoniais infinitas.

As categorias simbólicas que privilegiamos aqui correspondem a elementos estruturadores de forte apelo emocional, convergente de múltiplos de significados. O primeiro, advindo da comunicação religiosa, está polarizado pela mística imagética. No caso do Traslado rocieiro, automaticamente reconhecido pela figuração da própria Virgem, cujo auge místico da ritualidade festiva se encontra na tradicional procissão da madrugada de segunda-feira de Pentecostes.

$\mathrm{O}$ segundo elemento tratado, emerge da prática peregrina progressivamente convertida em turismo religioso. Trata-se do exercício interativo da visitação. Em Almonte, a visitação se estabe- 
lece no encontro - fraterno e conflitivo - entre as irmandades (Matriz e Filiais), seja na Aldeia de El Rocio, nos Caminhos Sagrados que levam até ela ou na celebração dos Traslados.

E o terceiro elemento, em sua projeção contemporânea, amplia os vínculos estritamente religiosos da comunidade de praticantes e fiéis para o âmbito público e cultural da devoção. Nele o valor religioso conforma-se em um patrimônio. Trata-se de uma complexa "ampliação em escala", gerando uma aparente e definitiva "dessacralização" do bem religioso (igreja, ritual, imagem, livros ou qualquer elemento da "tradição"). Contudo, tal aparência apenas encaminha a força da multiplicidade de acessos e interesses. Um patrimônio do cristianismo católico ou evangélico, tendo em vista sua intrínseca globalidade, independente do reconhecimento comunitário local; encontra-se envolvido por uma inclusão massiva à dinâmica da contemporaneidade, principalmente após as orientações ecumênicas e mundanas do Concílio do Vaticano II. Daí compreendermos caminhos e comunidades da Andaluzia rocieira, como um espaço triangular cujos vértices são Almonte/El Rocio/ Irmandades; e sua projeção (triângulo Y) o que a geografia regional denomina âmbito do Parque Donãna (Natural e Nacional). Este sim um patrimônio ambiental de referência para o cenário-base de todos os ritos devocionais ligados à cultura rocieira.

Diante da triangulação dessas categorias, lemos a estratégia devocional (que não deixa de ser comunicacional e turística e carnavalesca também) como desenho indispensável ao crescimento das múltiplas ritualidade. Se o legado das tradições entre as gerações atingiu a modernidade na configuração do atual sistema educacional/escolar, seu impacto pós-moderno - é o que evidenciamos nessa pesquisa - não abre mão de uma interdependência contextual e simbólica que requer aprendizagem valorativa. Neste sentido, uma aprendizagem que ultrapassa os significados dos conteúdos (disciplinas) em nome do sentido profundo dos símbolos (espetáculos). Tal sentido é aqui identificado como o complexo geoeducacional do Traslado da Virgem, no adensamento extraordinário de festividades rocieiras e andaluzas.

\section{A SÍNTESE VETORIAL DA GEOEDUCAÇÃO}

O propósito fundamental dessa "síntese" é permitir a convergência da análise sobre o patrimônio religioso (do traslado à devoção mariana) como meio de incorporar o debate sobre dois teoremas que levam em conta os fundamentos culturais do conhecimento geográfico.

A dimensão teórica que nos permite a síntese vetorial (ou modular) das categorias que reportamos acima emerge do trabalho seminal de dois pesquisadores contemporâneos da complexidade do espaço cultural. Pelo prisma da Geografia, o professor Paul Claval reúne uma constelação de elementos fundantes do patrimônio religioso em seu livro Religion et Idéologie: Perspectives géographiques (PUPS, 2008). Seu trabalho percorre o debate histórico da ciência geográfica em torno do mundo religioso, que desafiou tanto a perspectiva clássica da Geografia científica quanto a capacidade de respostas às implicações geopolíticas nos campos econômicos, ambientais e sociais. Mas é a esfera ideológica, articulada à formação educativa dos valores, que emergem de todos esses campos. O livro, portanto, enfrenta a relação ideologia moderna versus espacialidade religiosa como dimensões em diálogo, crescente e fértil. Não como "revestimento de um conteúdo", metáfora dominante em tantos críticos das ilusões da fé. O percurso proposto por Claval estrutura 10 capítulos que partem das investigações do religioso pelas ciências humanas. Avança na discussão dos temas religiosos mais sensíveis a experiência humana, como costumes, culturas regionais, rituais e mitos. Até reencontrar o dilema ideológico, na segunda metade do século XX, gregário dos jogos ambíguos de valores modernos e pós-modernos. Entre seus resultados, a secularização, ao contrário do que se imaginava em um racionalismo ingênuo, pode incluir muitos e diversificados sistemas de crença e convivência com o simbolismo religioso. Neste sentido depreendemos um mecanismo fundamental para constituir o que apresentaremos abaixo como teorema 1. Trata-se 
da ancestralidade, que religião e ideologia herdam uma da outra, continua e profundamente. $\mathrm{O}$ reconhecimento cristão da sustentabilidade ambiental da fé; e a inclusão do direito inalienável da liberdade de crenças e da mobilidade de cultos nos Estados laicos, são evidências marcantes de um atualizado legado ancestral.

O segundo autor que nos ampara é o estudioso da teoria artística, Patrice Pavis, que em 2008 publicou sua obra A Análise dos Espetáculos: Teatro, Mímica, Dança, Dança-Teatro, Cinema, em português pela Editora Perspectiva (tradução de Sérgio Salvia Coelho). O trabalho acolhe a multiplicidade ou pluralismo de abordagens para permitir ao leitor, não especialista, o verdadeiro universo semiótico que vem a ser a encenação contemporânea. E aqui, imediatamente, chegamos a outro elemento fundante para constituição de nosso segundo teorema. A encenação, ao requerer métodos adaptados plenamente ajustados aos seus objetos, expõe-se em triangulações que na obra de Pavis percorre a sequência: condições de análise, componentes da cena e condições de recepção. Fixamo-nos com maior atenção na segunda etapa, para absorver uma triangulação elementarmente vetorial entre o espaço, o tempo e a ação, que o autor vai reconhecer (por inspiração de Mikahil Bakhtin, 1895-1975) como um cronotopos. A interdependência dos três elementos vetoriais para que o corpo do ator/contexto se reconstitua "cenário em cena" formata esse cronotopos da encenação.

O termo cronotopo é entendido em toda sua relação com a teoria da relatividade de Einstein onde foi introduzido para indicar a interdependência entre o tempo e o espaço, e com a biologia. Nos estudos literários, o cronotopo é entendido como uma 'categoria conteudístico-formal' para examinar o processo de assimilação do tempo, do espaço e do indivíduo histórico real. (MACHADO, 1990, 141).

Trata-se de uma representação dialógica do tempo-espaço-bem religioso na construção de uma cultura devocional contemporânea. Assim como na análise de Pavis, podemos associar o Traslado, não só pela ancestralidade religiosa (facilmente compreendida até pelas comunidades escolares); também por sua encenação dinâmica, por sua "cronotopia" singular. Em que medida essa formulação pode conter um princípio generalizador, capaz de apontar teoremas para um fenômeno geográfico e teatral? Até que ponto, uma investigação empírica permite assentar uma sistematização teórica, ambicionando dois raciocínios de alto risco?

Abriremos os teoremas relembrando o pensamento Robert Kaplan, estrategista norte-americano, que vem reacendendo provocações do determinismo geográfico na interpretação das tendências conflituosas do século XXI. Seu trabalho visa os EUA (em especial) e as nações comprometidas com o ordenamento institucional democrático sobre o papel decisivo da geografia ambiental na continuidade de um desenho-mundo, elementarmente chamado de "mapa", por intermédio do qual não pode haver cena política desconectada do cenário geográfico. Quando, no capítulo 3 de sua obra, A Vingança da Geografia (2013), Kaplan convoca o conjunto de historiadores e geógrafos, tratados como "sucessores de Heródoto", e demonstra a força das intrigas humanas (incluindo a pulsão religiosa) para alcançar os limites geográficos formulando uma expressão síntese que vale a pena reproduzir aqui: Tudo é uma questão de geografia, até tornar-se uma questão shakespeariana! (KAPLAN, 2013: 60) Portanto, da ancestralidade contextual à encenação vivenciada em conexões de lugares distintos, o espaço geoducacional intensifica sua plasticidade em múltiplos vetores. Menos na estagnante compactação do currículo de geografia escolar. Voltaremos, após os teoremas vetoriais, a este ponto instigante.

A geoeducação das representações religiosas, por vias “externas” aos reducionismos do sistema escolar, fornece uma tessitura dos lugares geográficos no movimento tempo-espaço de sua celebração. Por essa razão consegue posicionar a captura (aprendizagem) humana adiante do direcionamento (ensino). Exatamente como as escolas e institutos de uma pretensa, quando não vazia "educação integral", insistentemente se recusam a fazer. O que não impede seu acesso pragmático e mundano no exercício compreensivo, emoldurado em sínteses ou representações dos sujeitos escolares. Em princípio: a) Todo lugar constitui-se em geograficidade mediante um traslado simbólico de 
pertencimento ancestral a outros lugares. E, por conseguinte, b) Todo saber geográfico legitima a aprendizagem na vitalidade relacional e encenada de dois ou mais lugares. Dediquemo-nos agora à decodificação mais detalhada de cada uma dessas formulações.

Formulando Teoremas: da geograficidade ancestral à vitalidade teatral.

Iniciemos pela crítica mordaz de Gaston Bachelard às limitações do ensino básico (incluindo o de Geografia), compatível com a necessidade de um novo espírito científico de tratamento aos teoremas.

Em resumo, no ensino elementar, as experiências muito marcantes, cheias de imagens, são falsos centros de interesse. É indispensável que o professor passe continuamente da mesa de experiências para a lousa, a fim de extrair o mais depressa possível o abstrato do concreto. Quando voltar à experiência, estará mais preparado para distinguir os aspectos orgânicos do fenômeno. A experiência é feita para ilustrar um teorema. (BACHELARD, 1996, 51)

O autor do clássico "A Filosofia do Não" é aqui relembrado porque ajudou, e muito, o pensamento ocidental (fluente, dialógico, inovador) a evitar a estagnação desse modelo de ilustração escolar. Daí o racionalismo múltiplo na produção de novos teoremas para enfrentar o "tesouro pueril de nossos esforços escolares”, segundo as palavras do filósofo. A ideia de teorema como afirmação que pode ser demonstrada não necessita de exatidões didáticas - cheias de plasticidade mágica das salas de aula e vazia dos fundamentos da ciência. Necessita de associação, de correlações dinâmicas sutilmente capitaneadas pela vivência do patrimônio geoeducacional, no ambiente lugar de sua profusão. Mesmo que (ou, exatamente porque) a escola desenhe um modelo curricular de lugar do saber de uma comunidade, é o saber do lugar - portanto, sua inversão racional - que dá substância, forma e conteúdo, a aprendizagem significativa. Malgrado toda a maleabilidade contemporânea que se pode reconhecer nas concepções dos currículos escolares (VALLE, 2008; HERNÁNDEZ CARDONA, 2002), um teorema aberto à formulação das representações do patrimônio geoeducacional não demanda qualquer elaboração curricular. Emergem simplesmente do oportuno reconhecimento antropológico e geográfico de que os lugares se identificam por ocupação pré-escolar. Mas a partir da escolarização das comunidades essa sintonia identitária pode caminhar para o interior dos sistemas de ensino; ou não (como habitualmente acontece).

Eis o primeiro teorema "demonstrável" da ação vetorial emissiva, considerando às variáveis comunicacionais e turísticas de sua formulação: Todo lugar constitui-se em geograficidade mediante um traslado simbólico de pertencimento ancestral a outros lugares. É necessário avisar, antes da decodificação do teorema, que a categoria "Lugar", fundada na abordagem humanista de Edward Relph (MARANDOLA; HOLZER; OLIVEIRA, 2012) como mundo de significações implicadas mobiliza a conceituação do mesmo em ambos os teoremas. Assim, o constituir-se em geograficidade (DARDEL, 2011) promove uma necessidade imitativa da fluidez, que certos pontos em certas condições favorecem. O teorema nos ajuda compreender que toda matriz de coordenadas terrestres é religiosamente acessível pelos símbolos religiosos. Mas cada ponto de contato de duas ou mais linhas de força, carrega tal densidade de significados que um lugar qualquer, imediatamente transfigura-se como o Lugar especial. Estando Nele, todos estarão sincronicamente em outro(s) lugar(es); como se realizassem um traslado simbólico por intermédio do evento festivo e ritual. A resposta de uma estudante frente sua participação no traslado de retorno da Virgem a Aldeia, sintetizava essa percepção de imponência do lugar como centro ancestral: Es la primera vez que vivo esta experiencia con conciencia, y volveré a repetirla cuantas veces pueda. E quando indagada sobre os benefícios... beneficia a la economía de Almonte (comércio especialmente); se conoce más a nuestro Pueblo. Estando em Almonte ela se via conscientemente em Andaluzia, na geograficidade espanhola da Terra. 
Contudo, o primeiro teorema, que expande o religioso na lógica emissiva, metáfora da gota d'água caindo e se dispersando em ondas de propagação, tende a ignorar outros eventos emissivos; muitos com os quais aquele que tomarmos como referencial se articula conflituosamente. É neste ponto que o vetor emissivo torna-se articuladamente receptor de uma construção centrada na própria escala terrestre. Sua formulação, inclusive parece contrariar a efeito monográfico e focal, frequentemente utilizado na escolha de um continente, país, região e, por extensão, um só lugar; como se a experiência humana imitasse um zoom ótico.

Diferentemente dessa linearidade em zoom, o teorema afirma: Todo saber geográfico legitima aprendizagem na vitalidade relacional e encenada de dois ou mais lugares. Neste sentido o zoom é bifurcado, uma, duas, três ou infinitas vezes. Isto porque o aprender da geoeducação - especialmente diante das múltiplas significações contidas em festejos religiosos desse porte - não se restringe a métodos sequenciais ou hierárquicos. A hierarquia, de fato é expressiva e articula etapas rituais marcantes do teorema anterior. Contudo, a referida aprendizagem, sustentada por processos relacionais, corresponde aos movimentos aleatórios capazes de conectar os mais diversos lugares o tempo todo. Não se trata, portanto, de selecionar conteúdos geográficos determinados em formalismos acadêmicos. Os mesmo que indicam, com perversa e paradoxal tranquilidade, que os saberes da cena e do cenário festivo não possuem representatividade pedagógica no currículo de geografia. O teorema é formulado pelo sentido espacial da vitalidade. Qualidade referencial desprezada na conceituação do que seja "geográfico" na escola. E é justamente a encenação teatral, no cotidiano significativo (harmônico ou conflitivo) das comunidades, que revitaliza o saber geográfico humano. Deste cotidiano é que o extraordinário alimenta seu lugar de referência habitual como o Lugar do Outro também, onde cada um se reinventa e a vitalidade se justifica nos caminhos e trajetos (esperados ou não).

Vejamos um exemplo na fala de dois estudantes envolvidos: o primeiro, quando perguntado o que mais o marcou disse: Vi a una inglesa llorar por que la estava viendo e entendi que no solo los almonteños la quieren. A segunda, destacando as datas de encerramento do traslado disse: El 5 de mayo vivi uma experiência muy bonita. Por ver a la virgen de reina por las calles de Almonte. El 12 de mayo cumplí uno de mis sueños de meterme a la virgen de pastora. Entre os seis alunos de IES La Ribera e os dois do IES Doñana, que retornam essa parte complementar do questionário (apontando a experiência do percurso da festa), privilegiamos a sutil percepção da alteridade. Um processo de amadurecimento identitário que o patrimônio religioso provê na consolidação do que, em outro estudo (OLIVEIRA, 2012) conceituamos como Alteridentidade. Trata-se de reconhecer o quando é fundamental associar o valor identitário de sua cultura, nas variações imagéticas que elas permitem diretamente (vi a Santa como Rainha; e revi, uma semana depois, como Pastora) ou que permitem indiretamente àqueles que se aproximam, embora aparentem distância (vi uma inglesa chorar pelo que imaginava ser possível ao povo de Almonte).

O lugar da festa irradia emissivas e receptivas formas de ancorar a representação do patrimônio religioso como geoeducação; seja na geograficidade ancestral dos símbolos que atraem e reverberam a devoção, seja na vitalidade teatral que multiplica aleatoriamente novos modelos de aprendizagem. O patrimônio religioso, portanto, é simultaneamente, conforme os teoremas, uma essência e infinitas imitações do lugar geográfico.

\section{CONSIDERAÇÕES FINAIS}

O traslado de retorno ao Rocio, concluindo o período de permanência da Virgem em Almonte dá-se na segunda semana de maio de 2013, com todo cerimonial previsto para conclusão triunfal do Ano Jubileu. A festividade ganhava um envolvimento mais eloquente das autoridades e fieis em um processo que duraria quase 24 horas (das $22 \mathrm{~h} 00$ de sábado, dia 12 às 21 do domingo 13/05). $O$ calor, a poeira e os desafios da travessia de 15 quilômetros retornavam dessa vez para aguardar a preparação da festa maior que o fim de semana de Pentecoste aguardava: o Rocio Grande e a famosa 
procissão de Lunes (segunda-feira), em um clamor popular de incomparável devoção pública. Um dos principais periódicos da região - Diário de Sevilla - assim noticiava o evento:

\section{Júbilo en EI Rocío por el regreso de su Pastora}

La Virgen llega a las 21:32 a su ermita rodeada de miles de fieles. Es el pistoletazo de salida de la romería: Ayamonte e Isla Cristina inauguran hoy los caminos onubenses.

La Virgen del Rocío ya preside su santuario marismeño en la aldea. Se pone fin a algo más de 6.500 horas en las que el altar de la ermita estuvo huérfano. Es ahora Almonte el que volverá a poner el cronómetro en marcha, a aguardar pacientemente siete nuevos años que le devuelvan su aliento espiritual, encarnados en una imagen que, desde 1949, regresa periódicamente a su pueblo. Aún con los ecos de la procesión que una semana antes la llevó a reinar por Almonte, la Pastora esperaba en la Parroquia Nuestra Señora de la Asunción el regreso triunfal a las marismas a las que da nombre, al mismo escenario donde lleva recibiendo cultos desde la primera mitad del siglo XIV.

Existía añoranza, casi prisas por volver a llevarla a recorrer las calles del municipio por segunda vez en este mes de mayo. A las 22:00 y prácticamente recién comenzado el rezo de la Salve, el sábado los almonteños corrían en masa para completar los escasos metros que los separaban de su Virgen. E1 tiempo se paró. En el exterior del templo, las escopetas transformaban la pólvora en un ensordecedor sonido que anunciaba el cariz especial del día. La madrugada se esfumó en un instante: el mismo que tardó la imagen en coronar el alto del molinillo del Chaparral, el escenario desde donde la Hermandad Matriz partirá el próximo miércoles para celebrar Pentecostés. En la emblemática explanada miles de personas se congregaron a presenciar otro de los momentos emotivos de la noche, ese instante que define el fin de la procesión y marca el comienza de la peregrinación a la aldea. A las 06:45, antes de que el sol se desperezase y abriese sus ojos, las camaristas se subían al altar y cubrían con el pañuelo el rostro de María. Acto seguido se la taparon con el guardapolvo que la habría de proteger durante todo el trayecto hacía la aldea. En ese momento el párroco de Almonte, José García, fue alzado a hombros de sus feligreses, para rezarle una Salve que recitaban hasta los niños pequeños.

Comenzaba ahí la segunda parte de la liturgia. El paso enfilaba el camino de los Llanos acompañado por las abuelas almonteñas que portaban los enseres, jarras y ráfagas de reina que hace escasamente una semana lucía la Virgen en la procesión Función de Iglesia. En la brújula un destino: la ermita, el lugar al que la Blanca Paloma llegaría 24 horas más tarde, tras recorrer tres leguas (15 kilómetros) y desafiar una densa nube de polvo.

http://www.diariodesevilla.es/article/sevilla/1521106/la/virgen/rocio/pasea/por/almonte.html

O retorno da Virgem, portanto, cumpre um destino plenamente articulado com o todo da festa devocional. Denota a interdependência do circuito que envolve religiosidade, lazer, turismo, cultura, em uma só política de reconhecimento do sacrifício pela mais nobre das causas: fazer do traslado mariano um teatro celestial de dois pólos indissociáveis, Almonte e El Rocio. Uma ritualidade local/ regional, cuja referência religiosa e patrimonial justifica todo e qualquer investimento, desde que este continue sob a égide condutora da Irmandade Matriz de Almonte. Metaforicamente, a organização portadora do Santo Gral e, em rituais como o Traslado, da geografia móvel e peregrina que o Santo Gral requer.

O que mais interessa reforçar, no encerramento dessa reflexão, é a captura - ainda que recortada pela ausência empírica no momento do retorno - das possibilidades de vivência docente, na construção de novos referenciais de cooperação geoeducativa. O encerramento do Bicentenário do Traslado e do Ano Jubileu (ocorrido em 08/09/2013) poderia ser interpretado como o fim de um ciclo. Terminado o episódio extraordinário, envolvendo toda cidade de Almonte em um cerimonial de nove meses contínuos, além da religiosidade habitual, seria justificada uma questão: A experiência do traslado, pelos vínculos geoeducacionais relatado, fortaleceria um plano de registro patrimonial da Cultura devocional à Virgem do Rocio? Não se descarta essa possibilidade principalmente pela intensa política de valorização patrimonial que a Comunidade Autônoma de Andaluzia e o Reino de Espanha promovem desde a consolidação democrática dos anos de 1980, que antecedeu o ingresso do país na União Europeia. O amplo processo de reconstrução democrática e fortalecimento 
regional arregimentou um papel indispensável para as forças culturais de identidade regional. É por esta via que a percepção de uma tendência à patrimonialização do complexo religioso-festivo do Rocio (material e imaterial) não se descarta.

Entretanto, é na esfera da representação social, especialmente aos docentes - já que os estudantes expressam de forma mais cristalina os valores hegemônicos da comunidade de Almonte - que o questionamento central dessa conclusão alcança interesse mais profícuo, no entendimento dos processos posteriores ao Traslado. Como as representações religiosas dos professores do Ensino Básico cooperam com a valorização patrimonial da geoeducação, seja em Almonte ou em qualquer outro lugar de irradiação devocional? Considerando uma ação pedagógica "diferenciada" do clamor dos festejos, similar a que vimos nos dois institutos investigados, pode-se concluir que o divórcio entre Planejamento escolar e Política religiosa do espaço cultural demarca um excelente nível de convivência por distanciamento das esferas de ação formativa. Profissionalmente, o professor na escola não demanda qualquer transferência da prática educativa ao universo religioso das irmandades, igrejas, celebrações ou procissões para que este se realize plenamente. Por esse caminho dicotômico - predominante neste e em outros estudos que coordenamos no Brasil - a geoeducação das representações religiosas implica em um processo de educação patrimonial completamente alienado do sistema escolar. O paradoxo do mesmo é constatar que outros sistemas institucionais da Sociedade Civil, como comércio, transportes, segurança pública, gestão ambiental, mercado imobiliário, por exemplo, conseguem interagir de forma significativa com o grande espetáculo devocional em curso. O próprio Rocio Grande, anualmente, dinamiza a polaridade da Aldeia do Rocio como se está se tornasse uma verdadeira capital da fé andaluza e das festividades massivamente ibéricas. Enquanto as escolas de Almonte e da Aldeia vivem seus dias de recesso!

Mas se tal realidade geoeducativa fosse menos apartada do sistema escolar, promovendo programações curriculares e temáticas correlacionadas a geograficidade e a vitalidade rocieira, ambos os patrimônios (o escolar e o religioso) estariam ameaçados? Ou isso poderia representar um investimento realmente inovador na comunicação patrimonial da escola como a cultura religiosa? E neste sentido as representações religiosas docentes cooperar mais para o amadurecimento dos saberes do lugar, conforme os teoremas?

Figura 4 - A Virgem retorna a Aldeia do Rocio

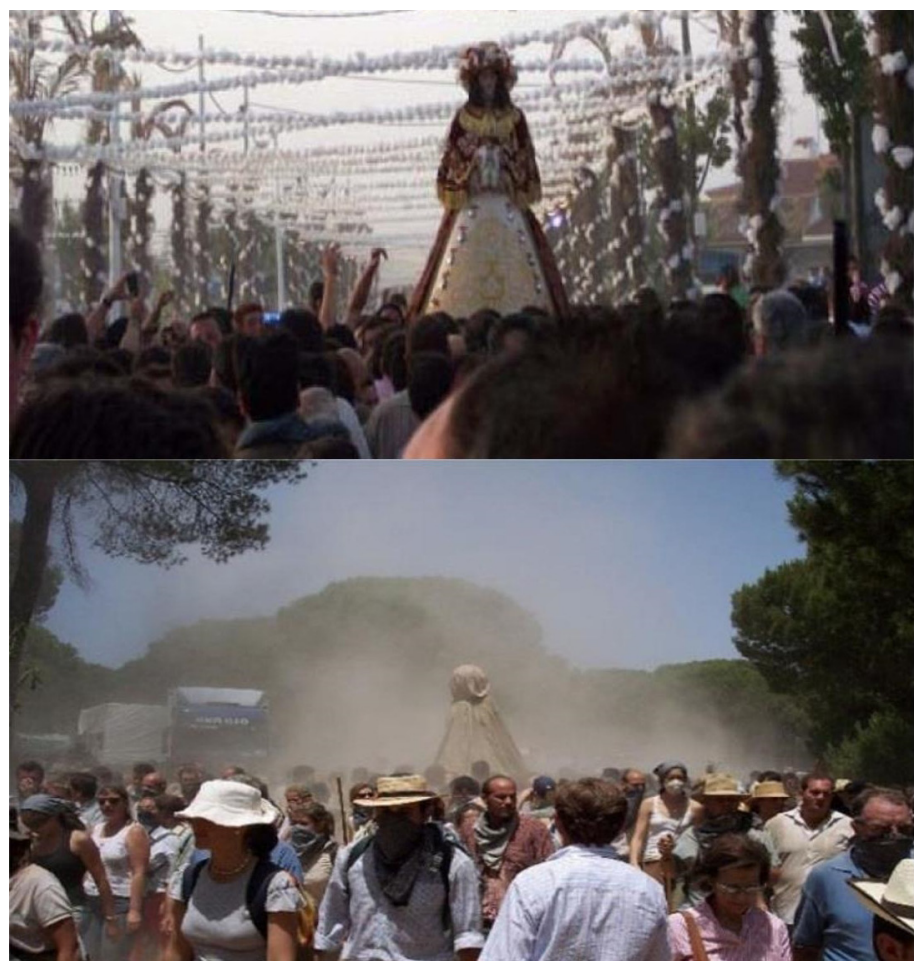

Fonte: Adaptação própria a partir de imagens do site http://www.rocio.com 
A hipótese levantada nos questionamentos acima demanda, evidentemente, novas trajetórias de investigação. As quais deverão correlacionar, de maneira experimental, mas indispensável, práticas de extensão, escolar e acadêmica, diretamente envolvidas na festa. O Traslado da Virgem do Rocio de 2012/2013 - pelo que as fotos da Figura 4 nos relembra, seja na cidade de Almonte ou no percurso a Aldeia - deu-se como um megaevento de pleno ordenamento territorial, extravasando escalas locais/regionais, e, portanto, operando uma Geografia Política da Religião como patrimônio cultural. Daí compreendê-lo como evento comunicacional, turístico e teatral associado espaço simbólico fluido. Ler, a partir dessa investigação, como tal evento poderá transitar da difusão geoeducacional para o nível curricular (especialmente da Geografia) requer significativa revisão da formação acadêmica docente. Formação esta que precisa acolher a dimensão patrimonial como coluna vertebral de qualificação do professor de Geografia.

\section{AGRADECIMENTOS}

O estudo aqui encerrado só foi possível à conjunção de três fontes de apoio institucional, que se mostraram sensíveis ao acolher o projeto de pesquisa Turismo e Patrimônio geoeducacional: construindo intercâmbios metodológicos a partir do evento "Traslado de la Virgen del Rocío" para Almonte (Huelva - Es). São elas: a Fundação Carolina de Espanha (que nos financiou passagem e recursos para permanência em Huelva por um mês durante o trabalho de campo); a Universidade de Huelva (UHU), que nos recebeu por intermédio dos Professores Faculdade de Educação, Dr. Jesus Estepa Gimenez e Dr. José María Cuenca López; e a Universidade Federal do Ceará (UFC), que nos liberou com todas as condições de oficiais necessárias, na certeza de que esse trabalho rendesse frutos a melhor qualificação de um profissional da casa na área de Geografia e Ensino, do Departamento de Geografia e do Centro de Ciências. Às três instituições, nosso mais sincero agradecimento.

\section{REFERÊNCIA BIBLIOGRÁFICA}

BACHELARD, G. A Formação do Espírito Científico. São Paulo, Contraponto, 1996.

CALA, Julio Flores. Historia y documentos de los traslados de la Virgen del Rocío a la Villa de Almonte 1607-2005, Centro de Estudios Rociero, Ayuntamiento de Almonte, 2005.

CLAVAL, Paul. Religion et Idéologie: Perspectives géographiques. Pari, PUPS, 2008.

CUENCA LÓPEZ, José María. El patrimonio en la didáctica de las ciencias sociales: análisis de concepciones, dificultades y obstáculos para su integración en la enseñanza obligatoria Tesis doctoral de la Universidad de Huelva, 2002

DARDEL, Eric. O Homem e a Terra: Natureza da Realidade Geográfica. São Paulo: Ed. Perspectiva, 2011 ESCALERA REYES, Javier. La fiesta como patrimonio. PH, Boletín, 21.p.53-58. Sevilla. IAPH 2009

HENARES CUELLAR, Ignácio L. La Proteccíon del Patrimonio Histórico en La España Democrática. Granada: Editorial Universidad de Granada, 2010.

HERNÁNDEZ CARDONA, F. Xavier. Didáctica de las ciencias sociales, geografía e historia. Barcelona: Graó, D.L. 2002.

INSTITUTO DEL PATRIMONIO CULTURAL DE ESPAÑA(IPCE); OBSERVATORIO DE EDUCACIÓN PATRIMONIAL EN ESPAÑA (OEPE). Comunicaciones del primero Congreso de Educación Patrimonial. Mirando la Europa: estado de la cuestión y perspectivas del futuro. Madrid 15 a 18 de octubre de 2012. $<$ http://ipce.mcu.es/portada/destacado37.html > [Consulta: 22 de enero de 2014]

KAPLAN, Robert. A Vingança da Geografia: A construção do Mundo Geopolítico a partir da perspectiva geográfica. Rio de Janeiro: Elsevier, 2013.

MACHADO, Irene. A Teoria do romance e a análise estético-cultural de M. Bakhtin. Revista USP, março, abril e maio de 1990. p. 135-142. http://www.usp.br/revistausp/05/19-irene.pdf. [Consulta: 20 de Jun de 2014] 
MARANDOLA JR., Eduardo. Fenomenologia e pós-fenomenologia: alternâncias e projeções do fazer geográfico humanista na geografia contemporânea. Revista Geograficidade v.3, n.2, Inverno 2013, 49-64. http://www.uff.br/posarq/geograficidade/revista/index.php/ geograficidade/article/view/123/pdf [Consulta: 20 de Abr 2014].

MARANDOLA, E.;HOLZER, W; OLIVEIRA, L. de. (org). Qual o Espaço do Lugar? São Paulo: Ed. Perspectiva, 2012.

MARTÍN CÁCERES, Myriam J. La educación y la comunicación patrimonial: una mirada desde el Museo de Huelva Tesis Doctoral de la Universidad de Huelva, 2012.

MUÑOZ BORT, Domingo. Patrimonio Municipal Público Villa de Almonte: 25 años de democracia municipal Almonte: Ayuntamiento de Almonte, Cuadernos de Almonte 95, 2007

PAVIS, Patrice. A Análise dos Espetáculos: Teatro, Mímica, Dança, Dança-Teatro, Cinema. São Paulo: Editora Perspectiva, 2008.

PERRENOUD, P. Construir as competências desde a escola. Porto Alegre: Artmed Editora. 1999

OLIVEIRA, C. D. M. de. Caminhos da Festa ao Patrimônio Geoeducacional: Como educar sem encenar Geografia. Fortaleza: Editora da UFC, 2012.

RODRIGUEZ BECERRA, Salvador. La Religión de los Andaluces. Málaga: Editorial Sarriá, 2006.

SÁ, Celso Pereira de. Núcleo Central das Representações Sociais. Petrópolis: Ed. Vozes, 1996

VALLE, Ione. O lugar dos saberes escolares na Sociologia Brasileira da Educação. Revista Currículo sem Fronteiras, v.8, n.1, pp.94-108, Jan/Jun 2008. http://www.curriculosemfronteiras.org/vol8iss1 articles/valle. pdf. [Consulta: 20 de Jun de 2014].

VICENTE CARMONA, José Luis de. El fenómeno religioso popular: valores y creencias: estudio de experiencias religiosas populares en Huelva a principios del siglo XXI. Tesis Doctoral presentada por José Luis de Vicente Carmona bajo la Universidad de Huelva. 2010

Trabalho enviado em julho de 2015 Trabalho aceito em agosto de 2015 